\title{
Morpho-Histometric Evaluations of Pre-Pubertal, Pubertal and Post-Pubertal Vesicular Gland of Indigenous Bulls of Bangladesh
}

\author{
Evaluaciones Morfohistométricas de la Glándula Vesicular Prepuberal, \\ Púberal y Postpuberal de Bovinos Nativos de Bangladesh
}

\author{
Gitaindro Nath Adhikary*; Mst. Ismat Ara Begum*; Muhammad Nazrul Islam**; \\ Kazi Mehetazul Islam* \& Shah Md. Abdur Rauf*
}

\begin{abstract}
ADHIKARY, G. N.; BEGUM, M. I. A.; ISLAM, M. N.; ISLAM, K. M. \& RAUF, S. M. A. Morpho-histometric evaluations of prepubertal, pubertal and post-pubertal vesicular gland of indigenous bulls of Bangladesh. Int. J. Morphol., 33(1):187-193, 2015.

SUMMARY: The present observation was aimed to evaluate the gross and histometric parameters of the vesicular glands of indigenous bulls. Twenty-eight bulls of three age groups were selected from the local market: the pre pubertal group A $(<1$ year $n=4)$, pubertal group B (1.5-2.5 years, $n=16$ ) and post pubertal or adult group C (above 3 years, $n=8)$. The weight, length (anterio-posterior), width (latero-medial) and the thickness (dorso-ventral) of the both left and right vesicular glands were recorded separately after slaughter of each animal. The left and right vesicular gland shows significantly different $(p<0.01)$, in weight and length in every group. Left vesicular glands were slightly higher than the right in all parameters. The lobules of the gland showed folded mucosa, lined with pseudostratified columnar epithelium. Three types of cells were identified in the epithelium containing A, B and C cell. Type A cells were tall columnar cells having distinct cell boundaries with the oval, round or elongated nucleus. Type B cells were located in the basal lamina having round or oval nucleus with indistinct cell boundaries. Type $\mathrm{C}$ cells were narrow columnar cells interspersed between A cells with darkly stained cytoplasm. Lamina propria consisted of loose connective tissue surrounded the alveoli, tubules and some solid end pieces. The numbers of secretory end pieces were variable. The diameters of luminated or non-luminated acini of the glandular end pieces and ducts were increased gradually and significantly $(\mathrm{p}<0.01)$ with the advancement of age. The epithelial height of the duct and alveoli were increased with the advancement of age, but no significantly differences among them. Tunica adventitia and muscularis grew with the advancement of age while the interstitial tissue shrunk equally. Above all parameters help to conclude that the vesicular glands of the pubertal indigenous bulls were more functional.
\end{abstract}

KEY WORDS: Vesicular gland; Indigenous bull; Histometry.

\section{INTRODUCTION}

Indigenous bulls are the greatest assets and heritage in compare to other important domestic animal of Bangladesh due to different disease resistant ability than other exotic breed, found all over the country. A great demand for indigenous bulls currently exists due to their early maturity, tasty, tender meat, high quality of the hide and local demand for religious sacrifices. For the sustainability of indigenous cattle population it is essential to use native breeding bulls of high reproductive performance. Testes are the primary reproductive organ responsible for the production of semen and androgen for maintain the reproductive health. The secretions of accessory genital glands are the seminal vesicles; the prostate and the bulbourethral glands regulate the ejaculatory process. The seminal vesicles having major role to produces viscid, yellowish secretion contains spermatozoa activating substances such as fructose, citrate, inositol, prostaglandins and several proteins acts as a source of energy for the sperm motility. Secretory product of the vesicular gland is rich in fructose, which serves as the energy source for ejaculated spermatozoa (Dellmann \& Eurell, 1998). The secretion of the accessory glands contributes for the most ejaculated volume (Ashdown \& Hafez, 1995; Campos 2003). The contribution of each gland to sperm volume varies among species, due to differences in gland size, and even absence of one, or more of them, in some species (Gonzalez, 2002). So, the testicular parameters in spermatozoa production equally important with gross and histometric parameters for vesicular secretion. Gross and histometric evaluations of vesicular gland of indigenous bulls were not available in the literature. This study was evaluated the gross and histometric parameters of vesicular gland in different stages of indigenous bull.

* Dept. of Animal Husbandry and Veterinary Science, Faculty of Agriculture, University of Rajshahi, Rajshahi, Bangladesh.

${ }^{* *}$ Dept. of Anatomy and Histology, Faculty of Veterinary and Animal Science, Sylhet Agricultural University, Sylhet, Bangladesh. 


\section{MATERIAL AND METHOD}

The experiment was conducted in the laboratory of the Department of Anatomy \& Histology, Sylhet Agricultural University, Bangladesh from July 2012 to June 2014. Twentyeight bulls of three age groups were selected from the local market before Muslim sacrifice on the year round: the prepubertal Group A (below 1 year $n=4$ ), pubertal Group B (1.5 to 2.5 years, $n=16$ ) and post pubertal or adult Group $C$ (above 3 years, $n=8$ ). The age was determined based on tooth eruption patterns (Getty, 1975). The animals were reared in animal shed of Sylhet Agricultural University. The bulls were kept individually in the stall and fed with ad libitum balanced ration for 4 weeks. Ante mortem examination of bulls was done before slaughter. The vesicular gland (right and left) was examined in situ position and the gross morphological parameters were recorded. The Vernier calipers and nonstretchable nylon thread were used in the measurements of length (anterio-posterior), width (latero-medial) and the thickness (dorso-ventral) of the both left and right vesicular glands were recorded separately of each animals in this study. The weight of the gland measured by digital electronic balance. The gland then cut into several pieces and collected few pieces of several areas for microscopic study. A part of each cut tissue samples were fixed in more than 20 times the volume of each in Bouin's fixatives for 24 hour, dehydrated in series of submerging progressively more concentrated ethyl alcohol $(70 \%, 80 \%, 90 \%, 95 \%, 100 \%)$. The tissues were kept for 3 hours in each grade of ethyl alcohol. Tissues were then transferred in a hydrophobic clearing agent, xylene in two changes to remove the ethyl alcohol. In both cases the tissues were kept for 40 minutes. Infiltrated the tissues through 2 changes of liquid paraffin in the micro oven taking 2 hours in each step to removethe xylene from tissues. When the tissues were dehydrated, cleared and infiltrated, they were placed in liquid paraffin for embedding, which were then allowed for hardening. This was achieved by cooling in the room temperature.

The hardened tissue blocks containing the tissue samples were then sectioned at 6 micron thickness using microtome (Microm GmbH, type HM 325, Germany) and the sections were floated in a water bath at 45 degree Celsius for flatten out on water. Then floated sections picked up carefully with clean slides, which have been smeared with Mayer's egg albumin and dried in the slide warmer. The successful sections were chosen and to ensure the different position of tissue about every 21 st section, the tissue examined were not in the same portion.

The sectioned tissue were deparaffinized by transferring them through xylene for two changes; 15 minutes in each case. Then these were transferred through descending grade of alcohol $(100 \%, 95 \%, 90 \%, 80 \%, 70 \%)$. Afterward these were passed through the normal water and distilled water. Tissues were stained with Hematoxylin and Eosin (Gridly, 1960). The tissue then dehydrated by transferring through baths of progressively more concentrated ethyl alcohol $(70 \%, 80 \%, 90 \%, 95 \%$, and $100 \%)$ and passed through xylene. Each slide was clean- blotted and mounted in Canada balsam under a cover slip. Four slides with four tissue sections in each slide made up per tissue sample were prepared for each bull.

The microscopic evaluation of vesicular gland included thickness of tunica adventitia, thickness of tunica muscularis, thickness of interstitial tissue, diameter of the luminated, non-luminate acini and epithelial height of the glandular end pieces, diameter of the duct and epithelial height of the duct. The data generated from this experiment were processed for further analysis. Mean value, standard error (SE) and correlations were estimated using the software Statistical Analysis System.

\section{RESULTS AND DISCUSSION}

The vesicular glands of indigenous bull were located on the dorso-lateral aspect of the neck of the urinary bladder (Fig. 1). It was lateral to the ampulla of vas deferens (Fig. 1) and the beginning part of the pelvic urethra. The glands were paired, compact and lobular. Its surface covered by a thick capsule of fibrous connective tissue. The lobulation of vesicular glands were distinct (Figs. 2A and 2B). These observations of the vesicular gland corroborate with the findings of bull (Getty, 1986; Nunez, 1993; Neves et al., 2013). At the junction of left and right vesicular gland with the union of ampulla and urethra a small area of fibrous cord present for connecting the gland. From the pre pubertal stage to adult or post pubertal the sizes become larger and lobulation become very much distinct. It was the similar observations of Asdell (1955), in bovines. Although Chandrapal (1976) reported that tubular shape with swollen ends in the neonatal and elongated with lobulations present in the pubertal buffaloes. This may be due to the species variation.

The gross morphological parameters of the vesicular gland of indigenous bull presented in Table I. In the prepubertal bull, the average weight, length, width and thickness were $3.87 \pm 0.15 \mathrm{~g}, 4.27 \pm 0.41 \mathrm{~cm}, 0.75 \pm 0.07 \mathrm{~cm}$ and $0.72 \pm 0.03 \mathrm{~cm}$ in the left vesicular gland and $3.71 \pm 0.21$ $\mathrm{g}, 4.01 \pm 0.37 \mathrm{~cm}, 0.75 \pm 0.06 \mathrm{~cm}$ and $0.68 \pm 0.01 \mathrm{~cm}$ in the right were respectively. In the pubertal bull, the average 
Table I. Gross morphological parameters of vesicular gland (Mean \pm SE) in indigenous bull from pre pubertal to adult stage ( $\mathrm{n}=24)$.

\begin{tabular}{|c|c|c|c|c|c|c|c|}
\hline \multirow{2}{*}{ SI $n$} & \multirow{2}{*}{ Parameters } & \multicolumn{2}{|c|}{ Pre pubertal } & \multicolumn{2}{|c|}{ Pubertal } & \multicolumn{2}{|c|}{ Post pubertal } \\
\hline & & Left & Right & Left & Right & Left & Right \\
\hline 1 & Weight (g) & $3.87 \pm 0.15^{* *}$ & $3.71 \pm 0.21 * *$ & $13.82 \pm 2.07 * *$ & $12.65 \pm 2.00 * *$ & $20.37 \pm 1.45^{* *}$ & $18.58 \pm 1.46^{* *}$ \\
\hline 2 & Length $(\mathrm{cm})$ & $4.27 \pm 0.41 * *$ & $4.01 \pm 0.37 * *$ & $7.55 \pm 0.36^{* *}$ & $7.23 \pm 0.38 * *$ & $9.18 \pm 0.70^{* *}$ & $8.86 \pm 0.60^{* *}$ \\
\hline 3 & Width $(\mathrm{cm})$ & $0.75 \pm 0.07^{\mathrm{NS}}$ & $0.75 \pm 0.06^{\mathrm{NS}}$ & $1.95 \pm 0.10^{* *}$ & $1.90 \pm 0.10^{* *}$ & $2.52 \pm 0.15^{* *}$ & $2.33 \pm 0.34 * *$ \\
\hline 4 & Thickness $(\mathrm{cm})$ & $0.72 \pm 0.03^{\mathrm{NS}}$ & $0.68 \pm 0.01^{\mathrm{NS}}$ & $1.41 \pm 0.11^{* *}$ & $1.28 \pm 0.10 * *$ & $1.58 \pm 0.09 * *$ & $1.51 \pm 0.07 * *$ \\
\hline
\end{tabular}

Asterisk $(*)$ indicates significant difference $(* \mathrm{p}<0.05, * * \mathrm{p}<0.01$ and $\mathrm{NS}=$ non significant $)$

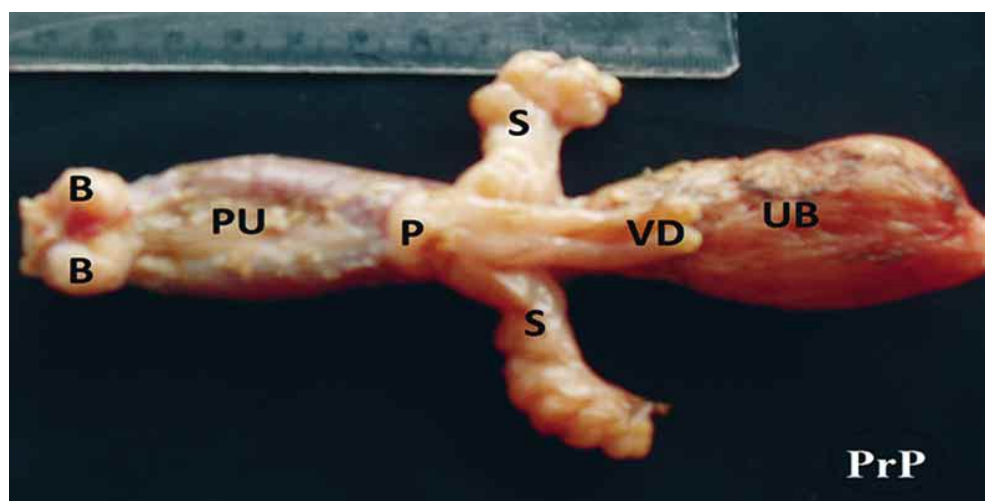

Fig. 1. Photomicrograph showing seminal vesicular (S) gland of prepubertal (PrP) bull vas deferens (VD), urinary bladder (UB), prostate gland $(\mathrm{P})$, pelvic urethra (PU) and bulbo urethral (B) gland.
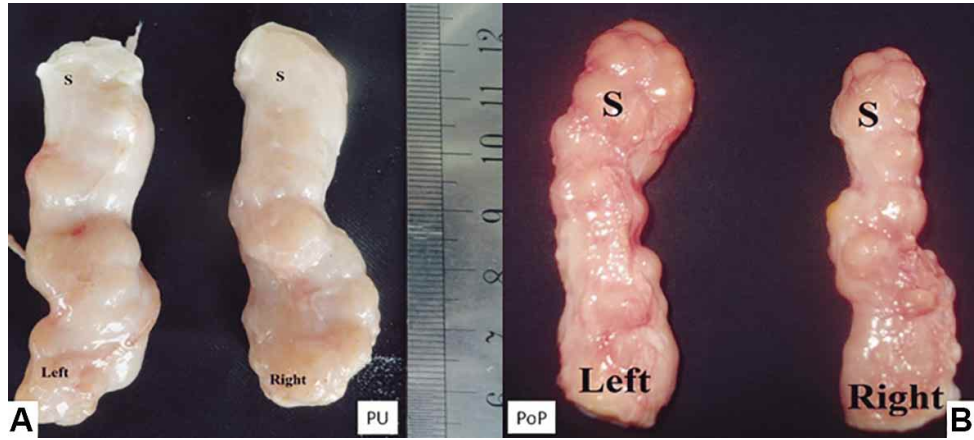

Fig. 2. The seminal vesicular gland (S) of pubertal (Pu) (Fig. 2A) and post pubertal (PoP) (Fig. 2B) stage showing right and left testis having multiple lobulation.

weight, length, width and thickness were $13.82 \pm 2.07 \mathrm{~g}, 7.55 \pm 0.36 \mathrm{~cm}$, $1.95 \pm 0.10 \mathrm{~cm}$ and $1.41 \pm 0.11 \mathrm{~cm}$ in the left vesicular gland, and $12.65 \pm 2.00 \mathrm{~g}, 7.23 \pm 0.38 \mathrm{~cm}, 1.90 \pm 0.10 \mathrm{~cm}$ and $1.28 \pm 0.01 \mathrm{~cm}$ in the right were respectively. In the adult bull, the average weight, length, width and thickness were $20.37 \pm 1.45 \mathrm{~g}, 9.18 \pm 0.70 \mathrm{~cm}, 2.52 \pm 0.15 \mathrm{~cm}$ and $1.58 \pm 0.09 \mathrm{~cm}$ in the left vesicular gland and $18.58 \pm 1.46 \mathrm{~g}$, $8.86 \pm 0.60 \mathrm{~cm}, 2.33 \pm 0.34 \mathrm{~cm}$ and $1.51 \pm 0.07 \mathrm{~cm}$ in the right were respectively (Table I). This result indicates that the left and right vesicular gland significantly different in weight and length in the present study. Left vesicular glands were slightly higher than the right in all parameters. This may be due to the usual variation, but no such available report in the literatures. The weight, length, width and thickness of the pre pubertal vesicular gland grew at very first to become pubertal stage than the pubertal to adult. The weight, length, width and thickness of left and right vesicular gland of pubertal and post pubertal group were significantly increased in the present study. These observations were similar to the results of Kundu (1980) and Gupta et al. (1993).

The lengths of the left and right vesicular gland were $7.55 \pm 0.36 \mathrm{~cm}$ and $7.23 \pm 0.38 \mathrm{~cm}$ in pubertal indigenous bull, $9.18 \pm 0.70 \mathrm{~cm}$ and $8.86 \pm 0.60 \mathrm{~cm}$ in the post pubertal or adult bull. This observation was dissimilar from the statement of Getty (1975) in bull, stated that the length of the vesicular gland was $10-12 \mathrm{~cm}$ and breadth $3 \mathrm{~cm}$. The present study was observed smaller and it may be the developmental status of indigenous bull of Bangladesh. The length and breadth of vesicular gland were $8.58 \mathrm{~cm}$ and $2.41 \mathrm{~cm}$ in indigenous adult bull of Bangladesh, were mostly similar to the present study (Rahman et al., 2010).

Histologically, the vesicular gland of indigenous bull was a lobulated compound tubulo-alveolar gland. It was described as Murrah bull (Sudhakar et al., 1986) and goats (Kundu). Each lobule consisted of tunica mucosa comprising lamina epithelialis and lamina propria, tunica muscularis and tunica adventitia. All three layers were similar to the description in different domestic animals (Trautmann \& Fiebiebiger, 1957; Dellmann \& Wrobel, 1976; Sudhakar et al.). The lobule of the gland showed folded mucosa, lined by the pseudostratified columnar epithelium. The central collecting sinus of each lobule had similar pseudostratified epithelium into which open the glandular tubes (Dellmann \& Eurell). Three type of cells were identified in the pseudostratified epithelium containing A, B and C. It was also described earlier in goat (Yao \& Eaton; Wrobel, 1970; Gupta \& Singh, 1982; Plöen, 1980;) sheep (Skinner et al., 1968; Singh et al., 1980) and buffalo (Sudhakar et al.). 
Type A cells were tall columnar cells having distinct cell boundaries with the oval, round or elongated nucleus. The cytoplasm of the cells were finely granular and faintly eosinophilic cytoplasm, but the apical border it became slightly basophilic in nature in the present study. This also the similar observation of Gaddi goats (Archana et al., 2009) stated that the late pre- pubertal Gaddi goats contained eosinophilic cytoplasm which stained relatively more darkly in the apical region. Type B cells were located in the basal lamina in between the type A cells having round or oval nucleus with indistinct cell boundaries. The shape of the cell was spherical and their cytoplasm was clear as described in goat (Archana et al.). Type $\mathrm{C}$ cells were narrow columnar cells interspersed between A cells with darkly stained cytoplasm with hyperchromic nuclei. They were fewer than the type $\mathrm{A}$ and $\mathrm{B}$ cells. The observation of type $\mathrm{C}$ cells were numerous in the pre pubertal bull, but rarely existed in pubertal and post pubertal bull. The similar findings were agreement with goat (Archana et al.) and buffalo (Sudhakar et al.). They noted that the type $\mathrm{C}$ cells were more in young and very less number in adult and concluded it might be intermediate stage in the cycle undergone by the epithelial cells.

Overall observations of three type cells, cytoplasm of cells were mostly vacuolated, eosinophilic with spherical to ovoid shape nuclei. These findings help to summarizes the type A cells having chief secretory function in the gland, type B cells were resting or reserve cells and type $\mathrm{C}$ cells were intermediate type between A and B cells. These disputation are also mentioned in different animals (Bhardwaj, 1960; Gupta, 1989).

Lamina propria consisted of loose connective tissue surrounded the alveoli, tubules and some solid end pieces. The numbers of secretory end pieces were variable. The smooth muscle and connective tissue pooled together to form connective tissue septa dividing gland proper of indistinct lobules. The interlobular connective tissue composed of circularly arranged collagenous bundles with reticular fibers, elastic fibers, fibroblast, smooth muscles and blood vessels. The interlobular connective tissue was preponderant in pre pubertal stage and the glands in per unit area were few. With the advancement age the glandular alveoli become larger and inter glandular connective tissue stroma was reduced.

The glands were compound tubule-alveolar appeared as luminated and non luminated described as in Beetal goats (Gupta) and in buffalo (Sudhakar et al.). The number of glandular unit increased in per unit area in the pre pubertal bull than the pubertal and adult. In the prepubertal bull, diameters of glandular end pieces were $113.00 \pm 16.20 \mu \mathrm{m}$ in the luminated acini and $69.00 \pm 7.37 \mu \mathrm{m}$ in the non-luminate acini. In the pubertal bull, diameters of glandular end pieces were $252.00 \pm 17.95 \mu \mathrm{m}$ in the luminated acini and $100.00 \pm 7.24 \mu \mathrm{m}$ in the non-luminate acini. In the post pubertal or adult bull, diameters of glandular end pieces were $304.00 \pm 21.01 \mu \mathrm{m}$ in the luminated acini and $143.00 \pm 8.17$ $\mu \mathrm{m}$ in the non-luminated acini (Table II). This observation indicated that the luminated or non-luminated acini of the glandular end pieces increased gradually and significantly with the advancement of age. These findings were accordance with the reported in goat (Archana). The diameters of luminated and non-luminated glandular end pieces were significantly increased, but radically increased from prepubertal to pubertal bull than the pubertal to adult. The glandular size was increased with the advancement of age with significantly changed from pre pubertal to adult. The glandular alveolar diameter increased gradually with the age and exposed apocrine mode of secretion. The central collecting sinus of each lobule united to form interlobular duct and several interlobular duct collectively form the excretory ducts of vesicular gland. The diameters of duct were increases significantly and radically from pre pubertal to pubertal bull than the pubertal to adult.

The lining epithelium of end pieces of vesicular gland was pseudo stratified columnar epithelium. In the pre pubertal bull, the epithelium showed simple cubiodal or simple columnar type (Fig. 3). Pseudo stratification was clear at the pubertal and adult bull in the vesicular gland in the present study (Figs. 4 and 5). The glandular alveoli, tubules and ducts were lined with epithelium similar to tunica mucosa. The lining cells were alsoA, B and C type like mucosa with similar cytological appearances. The epithelial height of glandular acini and duct were $10.00 \pm 0.64 \mu \mathrm{m}$ and $11.00 \pm 0.40 \mu \mathrm{m}$ in the prepubertal bull, $21.10 \pm 0.93 \mu \mathrm{m}$ and $20.80 \pm 0.68 \mu \mathrm{m}$ in the pubertal bull and $21.50 \pm 0.88 \mu \mathrm{m}$ and $21.30 \pm 0.59 \mu \mathrm{m}$ in the post pubertal bull, respectively (Table II). The present study indicated that epithelial height of the duct and alveoli increases with the advancement of bull, but no significantly difference among them. It was remarked that chief secretory cells A were did not grow structurally than the functionally attains at puberty or adult. These observations were in accordance with the Beetal goat (Gupta). Although, the increasing of the alveoli and decreasing in the epithelial height of the lumen of the vesicular gland of 7-8 month old Madras red ram lambs also observed (Naidu \& Pattabhiraman, 2001).

The muscularis layers were present in the covering of the vesicular gland surrounded the gland proper mainly the smooth muscle bundles arranged circularly in all three age group of indigenous bull. With the advancement of age the layer become significantly increased (Table II). 


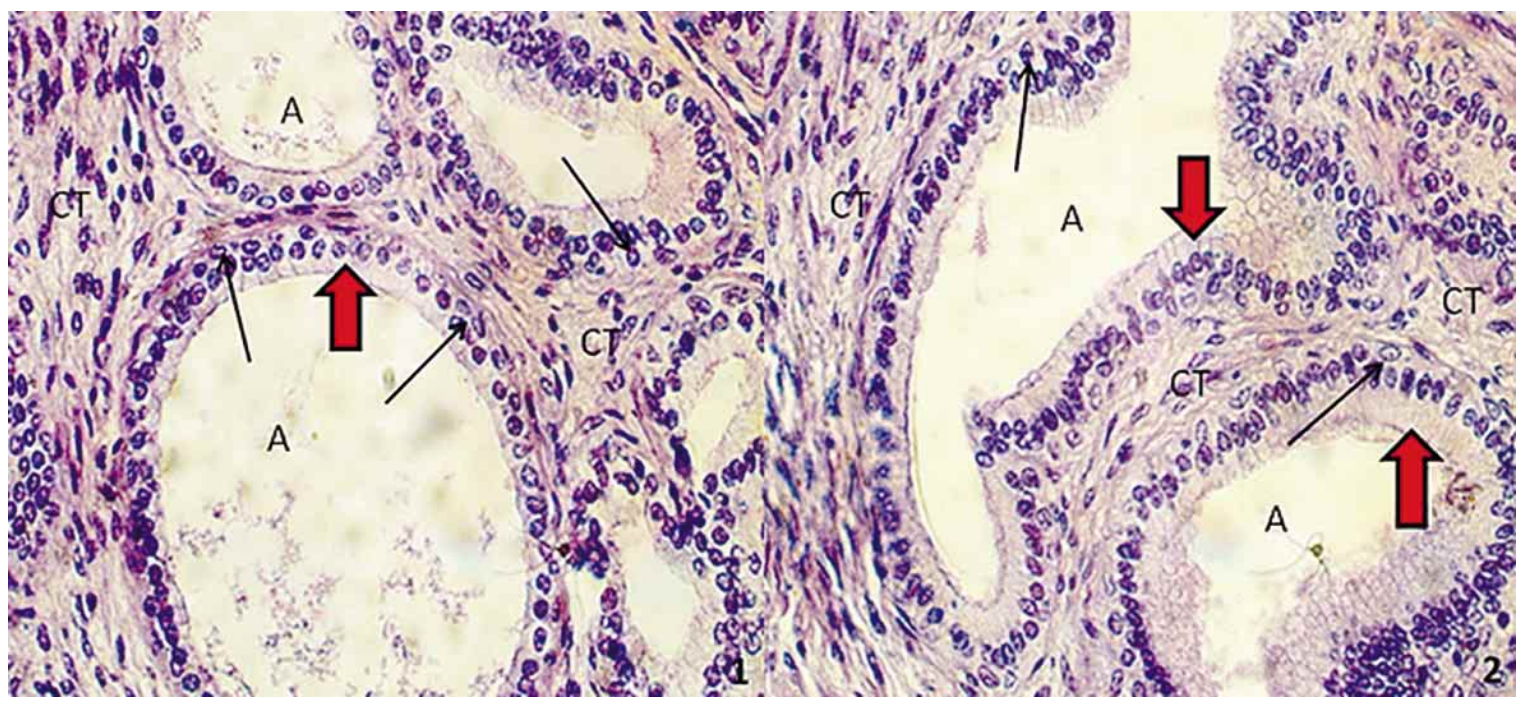

Fig. 3. Vesicular gland showing loose connective tissue septa (CT), secretory alveoli (A) with secretion, thick arrowhead pseudostratified epithelium showing type A cells and thin arrowhead basal cells of pre-pubertal bull. HE x40.

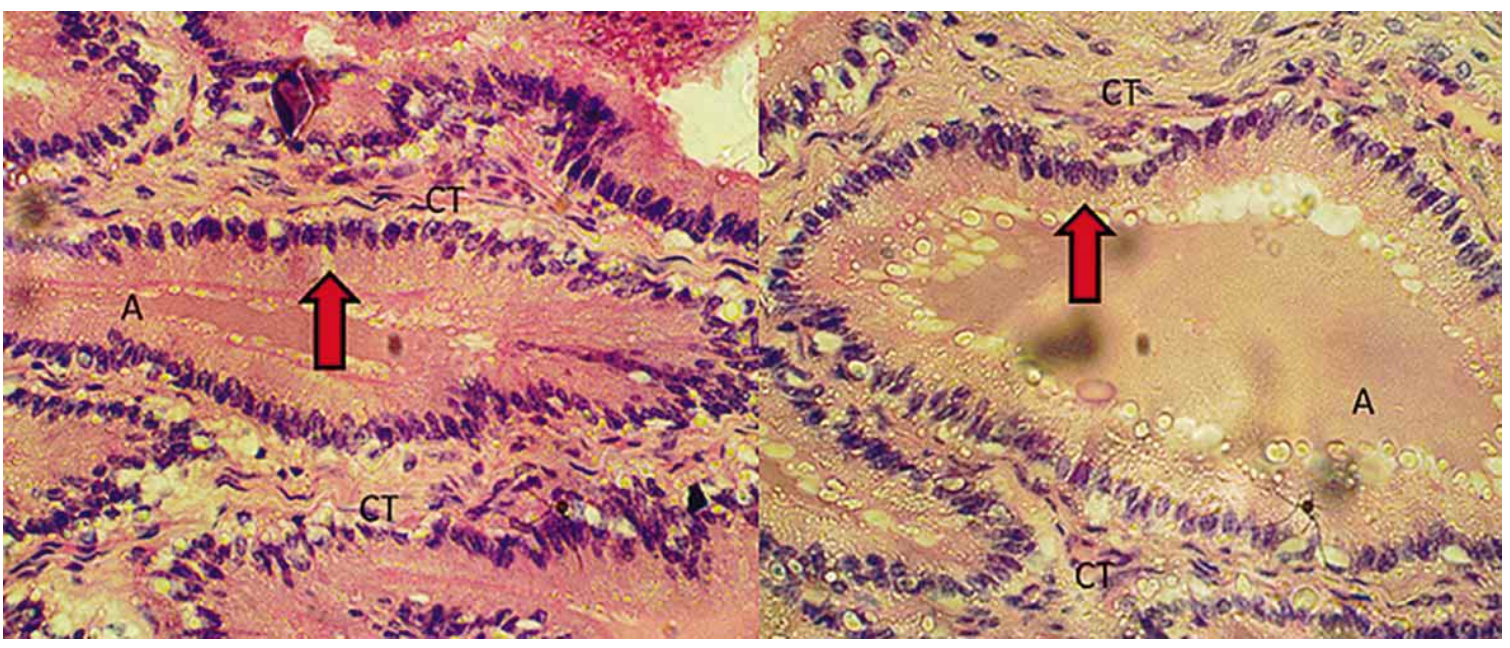

Fig. 4. Vesicular gland showing loose connective tissue septa (CT), secretory alveoli (A) with secretion, thick arrowhead pseudostratified epithelium showing type A cells of pubertal bull. HE x40.

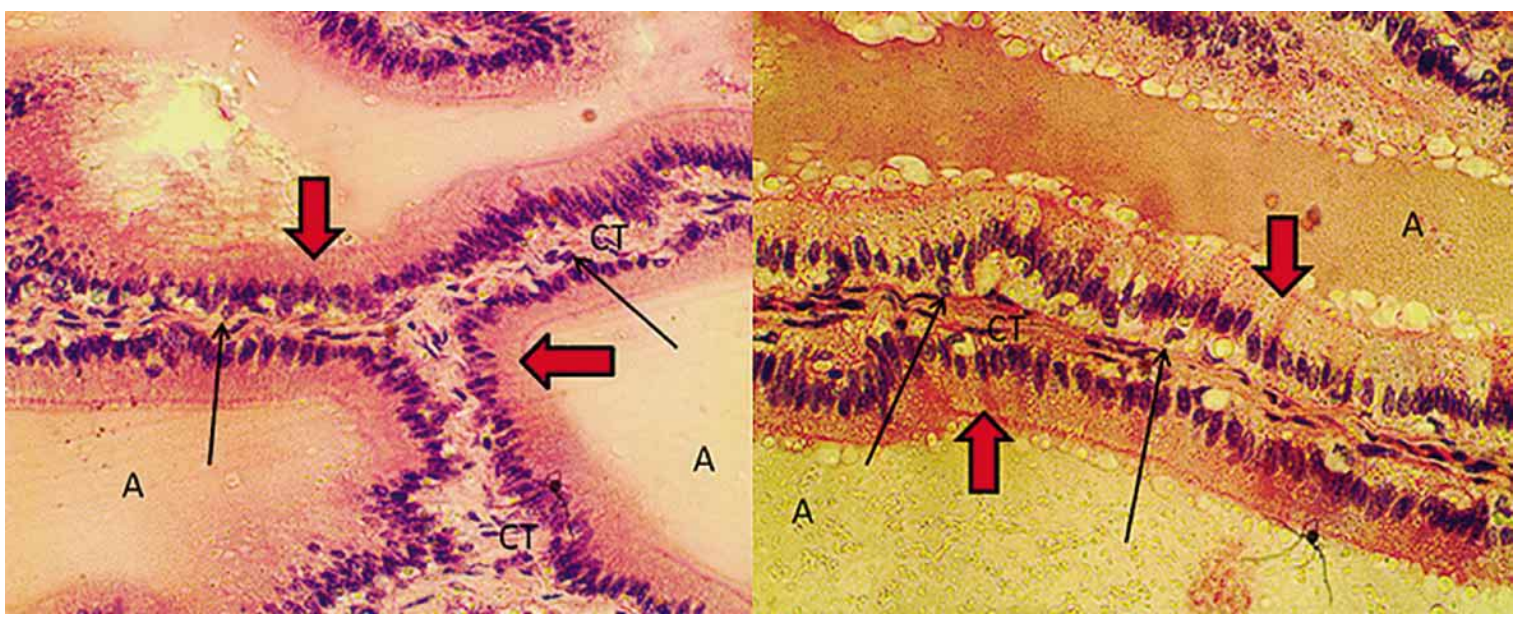

Fig. 5. Vesicular gland showing loose connective tissue septa (CT), secretory alveoli (A) with secretion, thick arrowhead pseudostratified epithelium showing type A cells and thin arrowhead basal cells of post pubertal bull. HE x40. 
Table II. Microscopic measurement of various component of vesicular gland (Mean \pm SE) in indigenous bull of different age group $(n=24)$.

\begin{tabular}{clccc}
\hline SI $\boldsymbol{n}$ & Parameters $(\boldsymbol{\mu m})$ & Pre pubertal & Pubertal & Post pubertal \\
\hline 1 & Thicknesses of tunica adventitia & $431.50 \pm 22.15^{* *}$ & $514.00 \pm 36.20^{* *}$ & $701.00 \pm 22.49^{* *}$ \\
2 & Thicknesses of tunica muscularis & $463.00 \pm 20.12^{* *}$ & $659.00 \pm 15.27^{* *}$ & $693.00 \pm 8.69^{* *}$ \\
3 & Thicknesses of interstitial tissue & $219.00 \pm 22.64 * *$ & $118.00 \pm 17.95^{* *}$ & $70.00 \pm 8.68^{* *}$ \\
4 & Glandular end pieces & & \\
& a) Diameter of luminated acini & $113.00 \pm 16.20^{* *}$ & $252.00 \pm 17.95^{* *}$ & $304.00 \pm 12.22^{* *}$ \\
& b) Diameter of non uminated acini & $69.00 \pm 7.37^{* *}$ & $100.00 \pm 7.24^{* *}$ & $143.00 \pm 8.17^{* *}$ \\
& c) Epithelial height & $10.00 \pm 0.64 \mathrm{~N}^{\mathrm{S}}$ & $21.10 \pm 0.93^{\mathrm{NS}}$ & $21.50 \pm 0.88 \mathrm{~N}^{\mathrm{s}}$ \\
5 & Duct & & \\
& a) Diameter of duct & $76.50 \pm 2.67^{* *}$ & $149.00 \pm 19.41^{* *}$ & $179.00 \pm 20.90^{* *}$ \\
& b) Epithelial height & $11.00 \pm 0.40 \mathrm{~N}^{\mathrm{S}}$ & $20.80 \pm 0.68^{\mathrm{No}}$ & $21.30 \pm 0.59 \mathrm{~N}^{3}$ \\
\hline
\end{tabular}

Asterisk $(*)$ indicates significant difference $\left(* \mathrm{p}<0.05,{ }^{*} \mathrm{p}<0.01\right.$ and $\mathrm{NS}=$ non significant $)$

The tunica adventitia composed collagenous connective tissue consisting of collagen, reticular and elastic fibers as described in goat (Gupta) and Buffalo (Sudhakar et al.). The many blood vessels, nerve fibers and autonomic ganglions were observed in the tunica adventitia as in man (Glenister, 1976). The histometric data of tunica adventitia showed that the continuous and progressive and significantly increased from prepubertal to adult stage of bull in the present study. Tunica albuginea was increased with the advancement of age described in buffalo (Sudhakar et al.). Tunica muscularis was similar trend except when the data on interstitial tissue was considered from prepubertal to pubertal and then adult stage. The notable changes were seen from the prepubertal to pubertal stage than between pubertal to adult stage. It was help to conclude that tunica adventitia and muscularis grew with the advancement of age while the interstitial tissue shrunk correspondingly. In the growth of the capsule, interlobular septa and in the interstitial tissue of the vesicular gland were similar trend as reported Beetal goats (Gupta) and ram (Singh et al.).

The gross and histometric parameters of vesicular gland with regard to different stages of indigenous bull, pubertal bull was the structurally significant in developmental changes. It might be help to conclude that the pubertal bull was more functional for the production of vesicular fluid as well as maintain the semen volume of the indigenous bull. Adult bulls represented as the structurally mature and the changes were significant but slower than the puberty indicated functional status become sluggish at maturity and decreased at older. So the suggestion for breeding bull was more reliable in pubertal to become adult indigenous bull through this revision of the glandular parameters.

ACKNOWLEDGEMENTS. The first author cordially acknowledges the faculty and staff of the Department of Anatomy \& Histology, Sylhet Agricultural University, Bangladesh for their assistance during his partial doctoral research work.
ADHIKARY, G. N.; BEGUM, M. I. A.; ISLAM, M. N.; ISLAM, K. M. \& RAUF, S. M. A. Evaluaciones morfohistométricas de la glándula vesicular prepuberal, puberal y postpuberal de bovinos nativos de bangladesh. Int. J. Morphol., 33(1):187-193, 2015.

RESUMEN: El presente estudio tuvo como propósito evaluar los parámetros macroscópicos e histométricos de las glándulas vesiculares de toros autóctonos. Veinticuatro toros fueron seleccionados en el mercado local y agrupados según la edad en: grupo prepuberal A ( $<1$ año; $n=4)$, grupo puberal $\mathrm{B}(1.5-2,5$ años; $\mathrm{n}=16$ ) y postpuberal o adulto $\mathrm{C}$ (por sobre 3 años; $n=8$ ). Se registró el peso, longitud (antero-posterior), ancho (latero-medial) y espesor (dorso-ventral) de las glándulas vesiculares izquierda y derecha por separado, después de sacrificado cada animal. Las glándulas vesiculares izquierda y derecha presentaron diferencia significativa $(\mathrm{P}<0,01)$ en cuanto al peso y longitud en cada grupo. Las glándulas vesiculares izquierdas fueron ligeramente mayores en relación a la derecha en todos los parámetros. Los lóbulos de la glándula mostraron una mucosa plegada, cubierta con epitelio columnar pseudoestratificado. Se identificaron tres tipos de células en el epitelio, conteniendo células de tipo A, B y C. Las células de tipo A eran células columnares altas con núcleos ovalados, redondos o alargados. Las células de tipo B se localizaron en la lámina basal, presentando un núcleo redondo o oval con límites celulares indistintos. Las células de tipo $\mathrm{C}$ eran células columnares estrechas intercaladas entre las células de tipo A, presentando un citoplasma oscuro. La lámina propia estaba constituida por tejido conectivo laxo, rodeada de alvéolos, túbulos y algunas piezas terminales sólidas. El número de extremos de secreción fue variable. El diámetro de los acinos con luz y sin luz de las piezas terminales y conductos glandulares aumentaron de manera gradual y significativa con el avance de la edad $(\mathrm{P}<0,01)$. La altura del epitelio del conducto y alvéolos aumentó con el avance de la edad, pero sin diferencias significativas entre ellos. Las túnicas adventicia y muscular aumentaron con el avance de la edad, mientras que el tejido intersticial se retrajo de manera proporcional. A partir de todos los parámetros analizados, se puede concluir que las glándulas vesiculares de los toros del grupo puberal fueron las más funcionales.

PALABRAS CLAVE: Glándula vesicular; Toro autóctono; Histometría. 


\section{REFERENCES}

Archana, P.; Katiyar, R. S.; Sharma, D. N. \& Farooqui, M. M. Gerentological Studies on the Gross and Histomorphology of the Vesicular Gland of Gaddi Goat (Capra hircus). Int. J. Morphol., 27(1):13-20, 2009.

Asdell, S. A. Cattle fertility and sterility. Toronto, Boston Lillie, Brown \& Company, 1955 .

Ashdown, R. R. \& Hafez, E. S. E. Anatomia da Reprodução Masculina. In: Hafez, E. S. E. (Ed.). Reprodução Animal. 6th ed. São Paulo, Manole, 1995. pp.3-20.

Bhardwaj, M. B. L. Histology of the urethra and accessory sex glands in the domestic animals and observations on the surgical insertion of the urinary bladder neck into descending colon in the dog. $\mathrm{PhD}$ Thesis. East Lancing, Michigan State University, 1960.

Campos, A. C. N. Morfometria do trato genital masculino: influência do plasma seminal obtido em época seca ou chuvosa sobre espermatozóides caprinos. Tese Doutorado em Ciências Veterinárias. Ceará, Faculdade de Veterinária, Universidade Estadual do Ceará, Fortaleza, 2003. pp.82.

Chandrapal, S. Gross histological and histochemical studies on the male genital system of buffalo (Bubalus bubalis). $\mathrm{PhD}$ thesis. Agra, Agra University, 1976.

Dellmann, H. D. \& Wrobel, K. H. Male reproductive system. In: Dellman, H. D. \& Brown, E. H. (Eds.). Text book of Veterinary Histology. Philadelphia, Lea and Febiger, 1976. pp.306-11.

Dellmann, H. D. \& Eurell, J. A. A Text Book of Veterinary Histology. 5th ed. Philadelphia, Williams and Wilkins, 1998. pp.226-35.

Getty, R. Sisson and Grossman's: The Anatomy of the Domestic Animals. Vol. 1. 5th ed. Philadelphia, W. B. Sounders Co., 1975.

Getty, R. Anatomia dos animais domestica. 6 ed. Rio de Janeiro,Interaamericana, 1986.

Glenister, T. W. Urogenital system. In: Hamilton, W. J. (Ed.). Textbook of Human Anatomy. 2nd ed. London, The Macmilan Press Ltd., 1976. pp.473-4.

Gonzalez, F. H. D. Introdução a Endocrinologia Reprodutiva Veterinaria. Porto Alegre, aboratório de Bioquímica Clínica Animal, 2002.

Gridley, M. F. Manual of Histologic and Special Staining Techniques. 2nd ed. New York, McGraw-Hill Book Co., 1960. pp.28-31, 8283.

Gupta, A. N. Correlative anatomy of the testes, epididymis and accessory sex glands in goat. PhD Thesis, Hisar, Chaudhary Charan Singh Haryana Agricultural University, 1989.

Gupta, A. N.; Singh, Y. \& Goyal, K. C. Morphometry of vesicular gland in relation to age and testicular growth in goat. Haryana Agric. Univ. J. Res., 23:69-72, 1993.
Gupta, A. N. \& Singh, Y. Effect of castration on the cytology of vesicular glands in goat. Indian J. Anim. Sci., 52:72-9, 1982.

Kundu, P. B. Anatomical studies on the accessory male sex glands (gross and microscopic) of the Indian goat (Jamunapari and cross Jamunapari). Indian J. Anim. Health, 19:151-3, 1980.

Naidu, K. V. \& Pattabiraman, S. R. Postnatal development of seminal vesicle in Madras Red ram lambs maintained under different feeding system. Indian J. Anim. Reprod., 22:154-8, 2001.

Neves, C. C.; Artoni S. M. B.; Pacheco, M. R.; Feliciano, M. A. R.; Amoroso, L. \& Melo, D. G. Morphology and biometric of the vesicular and bulbourethral glands in castrated and non-castrated Santa Ines breed sheep. J. Morphol. Sci., 30(2):115-20, 2013.

Nunez, Q. M. Morphologia del tract genital de los pequeños ruminates. Rev. Cient. FCV. Luz, 3(2):77-86, 1993.

Plöen, L. Electron microscopic observations on the epithelium of ram seminal vesicles. J. Anat., 130(Pt. 3):507-11, 1980.

Rahman, M. S.; Islam, M. S.; Rahman, M. T.; Parvez, N. H. \& Rahman, M. M. Morphometric analysis of vesicular glands of indigenous bull. Int. J. Sustain. Crop Prod., 5(1):11-4, 2010.

Singh, Y.; Singal, S. P. \& Lohan, I. S. Histological \& histochemical studies on the gonadotrophin treated vesicular glands of prepuberal rams. Indian J. Exp. Biol., 18(7):719-22, 1980.

Skinner, J. D.; Booth, W. D.; Rowson, L. E. \& Karg, H. The post-natal development of the reproductive tract of the Suffolk ram, and changes in the gonadotrophin content of the pituitary. J. Reprod. Fertil., 16(3):463-77, 1968.

Sudhakar, L. S.; Dhingra. L. D. \& Sharma D. N. Postnatal histomorphology of the vesicular gland in Murrah buffalo bull. Indian J. Anim. Sci., 56:866-9, 1986.

Trautmann, A. \& Fiebiger, J. Fundamentals of Histology of Domestic Animals. Ithaca, Comstock Pub. Associates, 1957. pp.269-72.

Wrobel, K. H. Morphology of the epithelium of seminal vesicles in the goat. Zentbl. Vet. Med., 17:634-43, 1970.

Yao, T. S. \& Eaton, O. N. Postnatal growth and histological development of reproductive organs in male goats. Am. J. Anat., 95(3):401-31, 1954.

\section{Correspondence to:}

Gitaindro Nath Adhikary

Associate Professor

Dept. of Anatomy and Histology

Sylhet Agricultural University

Sylhet-3100

BANGLADESH

Email: adhikarygn.dah@sau.ac.bd

Received: 08-10-2014

Accepted: 24-12-2014 